\title{
KESESUAIAN AKAD MURABAHAH DENGAN PEMBIAYAAN KEPEMILIKAN RUMAH BANK JATIM UNIT USAHA SYARIAH'
}

\author{
Riza Arsita Sari \\ Departemen Ekonomi Syariah-Fakultas Ekonomi dan Bisnis-Universitas Airlangga \\ Email: arsitasari96@gmail.com \\ Irham Zaki \\ Departemen Ekonomi Syariah-Fakultas Ekonomi dan Bisnis-Universitas Airlangga \\ Email: irhamzaki@gmail.com
}

\begin{abstract}
:
The research objectives were to find out the suitability of the murabahah contract on home ownership financing of Bank Jatim sharia business unit. The research objects were the employees of Bank Jatim Sharia who were competent in the field of financing analyst for Griya iB Barokah KPR (public housing loan). This research used descriptive qualitative approach. The data collection was conducted by interviewing five employees of Bank Jatim sharia business unit. The results of this study was, there were four points that were used as references for conducting research, namely prices, guarantees, fines, bad financing of KPR products which in practice were in accordance with DSN-MUI fatwas. Additionally, some did not.
\end{abstract}

Keywords: murabahah contract, sharia KPR, DSN-MUI fatwas, Bank Jatim sharia business unit.

\section{PENDAHULUAN}

Peran sebagai perantara antara unit-unit ekonomi yang kelebihan dana dengan unit unit yang kekurangan dana. Sebagai lembaga perantara tentunya bank syariah dapat menyalurkan kelebihan Perbankan Syariah di Indonesia telah menjadi tolak ukur keberhasilan eksistensi ekonomi syariah. Bank Muamalat sebagai bank syariah pertama dan menjadi pioneer bagi bank syariah lainnya telah terlebih dahulu menerapkan sistem ini ditengah menjamurnya bank-bank konvensional. Krisis moneter yang terjadi pada tahun 1998 telah menenggelamkan bank-bank konvensional dan dilikuidasi karena kegagalan sistem bunganya. Sementara perbankan yang menerapkan sistem syariah dapat tetap mampu bertahan

Bank syariah memiliki dana dari unit yang kelebihan pada yang membutuhkan sehingga mampu memberikan manfaat. Kualitas bank syariah sebagai lembaga intermediary ditentukan oleh manajemen bank untuk melaksanakan perannya.

Bank syariah memiliki ketentuan yang berbeda dengan bank konvensional dalam memenuhi modal serta penyaluran pembiayaan. Dapat dilihat produk-produk bank terdiri atas tiga kategori, yaitu: produk penyaluran dana (financing), produk penghimpunan dana (finding).

Pembiayaan murabahah merupakan produk yang mirip dengan kredit konvensional pada bank umum,

\footnotetext{
${ }^{1}$ Jurnal ini merupakan bagian dari skripsi Riza Arsita Sari, NIM: 041411431061, yang diuji pada tanggal 8 Mei 2019.
} 
selain itu masyarakat memilih produk tersebut karena memberikan kenyamanan saat bertransaksi. Perbankan syariah masih pada tahap awal, sehingga masyarakat masih mencari produk yang hampir mirip dengan konvensional. Piutang murabahah juga dibayar setiap bulan melalui cicilan (Karim, 2008). Melihat pernyataan diatas maka masyarakat lebih menyukai transaksi dengan akad murabahah dengan alasan akad ini lebih dikenal dan memiliki kesamaan dengan produk bank konvensional. Murabahah adalah salah satu akad jual beli barang dengan harga asal ditambah keuntungan yang disepakati antara bank dan nasabah (Sudarsono, 2008 : 69).

Pembiayaan murabahah merupakan pembiayaan yang lebih dominan dibanding dengan pembiayaan lain yang ditawarkan oleh bank syariah. Karena resiko yang diberikan dari pembiayaan murabahah kecil. Murabahah merupakan akad jual beli yang menggunakan sistem margin, pihak bank membeli barang dari bank dengan keuntungan (margin) yang diberikan kepada bank sebagai imbalan jasa bank memberi pembiayaan kepada nasabah. Dalam transaksi akad murabahah barang diserahkan segera sesudah akad, sementara pembayaran dilakukan secara tangguh. Pembiayaan murabahah memberikan jaminan atas kesepakatan akad yang telah dilakukan oleh kedua belah pihak, jaminan yang diberikan bertujuan untuk menghindari adanya pembiayaan macet yang dilakukan oleh nasabah. Jika nasabah pembiayaan murabahah mengalami bangkrut dalam pembayaran maka bank syariah wajib memberi kelonggaran pembiayaan sampai nasabah yang berhutang dapat membayar hutangnya kembali.

\section{LANDASAN TEORI}

\section{Perbankan Syariah}

Berdasarkan UU. No 21 Tahun 2008 tentang perbankan syariah bahwa perbankan syariah adalah segala sesuatu yang menyangkut tentang Bank Syariah dan Unit Usaha Syariah, mencakup kelembagaan, kegiatan usaha, serta cara dan proses dalam melaksanakan kegiatan usahanya. Bank Syariah adalah bank yang menjalankan kegiatan usahanya berdasarkan prinsip syariah (BUS), unit usaha syariah (UUS) dan bank pembiayaan rakyat syariah (BPRS).

Menurut Sudarsono dalam Bank dan Lembaga Kevangan Syariah (2008:27) pada umunya yang dimaksud Bank Syariah adalah lembaga keuangan yang usaha pokoknya memberikan kredit dan jasa-jasa lain dalam lalu lintas pembayaran serta peredaran vang yang beroperasi diseusaikan dengan prinsip prinsip syariah. Oleh karena itu, usaha bank akan selalu berkaitan dengan masalah vang sebagaimana dagangan utamanya.

Bank syariah merupakan bank yang secara operasional berbeda dengan bank konvensional. Salah satu ciri khas bank syariah yaitu tidak menerima 
atau membebani bunga kepada nasabah, akan tetapi menerima atau membebankan bagi hasil serta imbalan lain sesuai dengan akad-akad yang diperjanjikan. Konsep dasar bank syariah didasarkan Al-Qur'an dan hadits. Semua produk yang ditawarkan tidak boleh bertentangan dengan isi Al-Qur'an dan hadits (Ismail, 2011:29). Pada berbagai macam produknya, baik penghimpunan dana maupun penyaluran dana dapat menggunakan sistem bagi hasil margin atau fee.

\section{Pembiayaan}

Menurut Antonio (2001: 160)
adalah penyediaan dana untuk
memenuhi kebutuhan pihak-pihak yang
merupakan defisit unit. Sedangkan
menurut undang-undang perbankan No.
10 Tahun 1998, pembiayaan adalah penyediaan vang atau tagihan yang dapat disamakan dengan itu, berdasarkan persetujuan atau kesepakatan antara bank dengan pihak lainyang mewajibkan pihak yang dibiayai untuk mengembalikan uang atau tagihan tersebut setelah jangka waktu tertentu dengan imbalan bagi hasil.

Menurut Muhammad (2011: 304) menjelaskan pembiayaan secara luas berarti financing atau pembelanjaan, yaitu pendanaan yang dikeluarkan untuk mendukung investasi yang telah di rencanakan dengan baik dilakukan sendiri maupun dijalankan dengan orang lain. Dalam arti sempit, pembiayaan dipakai utnuk mendefinisikan pendanaan yang dilakukan oleh lembaga pembiayaan, seperti bank syariah kepada nasabah.

\section{Murabahah}

Murabahah didefinisikan oleh para fuqaha sebagai penjualan barang seharga biaya atau harga pokok (cost) barang tersebut ditambah mark- up atau margin keuntungan yang disepakati. Menurut Fatwa DSN (Dewan Syariah Nasional) dijelaskan bahwa yang dimaksud dengan Murabahah (DSN, 2003:311) adalah menjual suatu barang dengan menegaskan harga belinya dan pembeli membayarnya dengan harga yang lebih sebagai laba.

Dalam praktik perbankan, Murabahah lazimnya dilakukan dengan cara pembayaran cicilan. Dalam transaksi ini barang diserahkan segera setelah akad, sedmentara pembayaran dilakukan secara tangguh. Dalam jual beli secara umum, mekanisme pembayaran secara tunai, dengan mekanisme Murabahah, jual beli menjadi bersifat tangguh dalam pembayaran, serta penjual dapat mengambil keuntungan dari barang yang di beli.

\section{Pembiayaan Murabahah Di Bank Syariah}

Pembiayaan murabahah merupakan jenis pembiayaan yang sering diaplikasikan dalam bank syariah, yang pada umumnya digunakan pada transaksi jual beli barang investasi dn barang-barang yang diperlukan oleh individu. Jenis penggunaan pembiayaan murabahah lebih sesuai untuk 
pembiayaan investasi dan konsumsi. Dalam pembiayaan konsumsi, biasanya barang yang akan dikonsumsi oleh nasabah jelas dan terukur. Pembiayaan murabahah kurang cocok untuk pembiayaan modal kerja yang diberikan langsung dalam bentuk uang.

\section{KPR Syariah}

KPR syariah merupakan salah satu produk pembiayaan yang ada pada bank syariah. Kebutuhan akan tempat tinggal berkembang pesat seiring dengan permintaan masyarakat memiliki hunian yang digunakan untuk konsumtif atau sebagai investasi. Bank syariah akhirnya membuat produk KPR syariah yang mempunyai perbedaan dengan KPR konvensional. Perbedaan nya terletak pada pembayaran angsuran. Jika pada bank syariah pembayaran angsuran tidak berubah dari awal terjadi kesepakatan akad antara kedua pihak karena bank syariah menggunakan sistem bagi hasil.

Pembiayaan Kepemilikan Rumah dengan

\section{Akad Murabahah}

Haris (2007:115) dalam jurnalnya menjelaskan produk pembiayaan KPR yang digunakan dalam perbankan syariah memiliki berbagai macam perbedaan dengan KPR di perbankan konvensional. Hal ini merupakan impilkasi dari perbedaan prinsipal yang diterapkan perbankan syariah dan perbankan konvensional adalah konsep bagi hasil dan kerugian sebagai pengganti sistem bunga perbankan konvensional. Dalam produk pembiayaan kepemilikan rumah, terdapat beberapa perbedaan antaranya adalah pemberlakuan sistem kredit dan sistem mark up kebolehan dan ketidakbolehan tawar menawar anta nasabah dengan bank, produser pembiayaan dan lain sebagainya.

Pembiayaan kepemilikan rumah pada bank syariah dengan menggunakan akad murabahah adalah nasabah dapat membeli rumah dengan menggunakan sistem tangguh atau bisa langsung dengan sistem tunai. Namun diawal perjanjian antara kedua belah pihak dari awal sudah melakukan kesepakatan dimana pihak bank memberitahu kepada nasabah berapa harga rumah yang diberikan oleh developer, lalu pihak bank memberitahu kepada nasabah berapa harga rumah yang diberikan dan margin keuntungan yang diberikan kepada pihak bank sebagai penyalur anatar developer dengan nasabah.

\section{Dewan Syariah Nasional Majelis Ulama Indonesia (DSN-MUI)}

Pembentukan

DSN-MUI

merupakan langkah efisiensi dan koordinasi para ulama dalam menanggapi isu-isu yang berhubungen dengan masalah ekonomi dan keuangan. Berbagai masalah yang memerlukan fatwa akan ditampung dan dibahas bersama agar diperoleh kesamaan pandangan dalam penanganannya oleh masing-masing Dewan Pengawas Syariah (DPS) yang ada di Lembaga Keuangan Syariah. 
Fatwa DSN-MUI Tentang Murabahah dan Penanganan Pembiayaan

Fatwa DSN-MUI yang mengatur murabahah terdapat pada Fatwa no.04/DSN-MUI/IV/2000 tentang Murabahah, Fatwa no. 13/DSN$\mathrm{MUI} / \mathrm{IX} / 2000$ tentang vang muka Murabahah, fatwa no. 17/DSNMUI/IX/2000 tentang saksi atas nasabah mampu yang menunda-nunda pembayaran dan fatwa no.47/DSNMUI/II/2005 tentang penyelesaian piutang murabahah. Secara rinci dapat dijelaskan sebagai berikut :

Fatwa No. 04/DSN-MUI/IV/2000 tentang murabahah.

Pada dasarnya pengertian murabahah adalah akad jual beli antara bank dengan pihak nasabah, dimana pihak bank menegaskan harga pembelian barang yang dibeli oleh nasabah beserta keuntungan yang diperoleh bank dan pembayaran dilakukan secara tangguh. Berdasarkan ketentuan fatwa di atas pembiayaan produk KPR syariah dengan menggunakan akad Murabahah berdasarkan persyaratan, prosedur, biaya dan harga akad,denda murabahah, jaminan atas murabahah telah diatur untuk menjadi landasan dalam melakukan transaksi perbankan.

III. METODE PENELITIAN

\section{Pendekatan Penelitian}

Penelitian ini menggunakan pendekatan kualitatif, yakni sebuah pendekatan penelitian dengan latar mengeksplorasi fenomena atau gejala sosial yang terjadi agar hasil penelitian yang diperoleh dapat dijadikan sebagai bahan pelajaran yang bermanfaat dan memeberikan kontribusi terhadap pengembangan konsep teori. Pendekatan kualitatif ini digunakan karena dalam penelitian terkait kesesuain fatwa DSN-MUI dalam prosedur akad murabahah dan musyarakah mutanaqishah pada pembiayaan kepemilikan rumah ditujukan untuk memahami sebuah fakta dibalik fenomena untuk mendapat gambaran secara jelas tentang kondisi sebenarnya dalam pembiayaan kepemilikan ruma dalam akad murabahah.

Penelitian ini bertujuan untuk menjawab rumusan masalah yaitu "Kesesuaian akad murabahah pada pembiayaan kepemilikan rumah bank jatim unit usaha syariah" alasan menggunakan metode kulaitatif pada penelitian ini adalah penelitian ini tidak bertujuan melakukan uji hipotesis dengan metode statistik ataupun ekonometri.

Studi kasus menurut Yin (2009:18) adalah suatu inkuiri empiris yang menyelidiki fenomena di dalam konteks kehidupan nyata, bilamana batas-batas anatara fenomena dan konteks tak tampak dengan tegas dan dimana sumber bukti dimanfaatkan. Strategi studi kasus memungkinkan hasil penelitian sulit untuk memanipulasi karena dalam studi kasus hanya memiliki sedikit peluang untuk 
mengontrol peristiwa-peristiwa yang akan terjadi.

Yin (2009 :29) menjelaskan terdapat lima komponen yang sangat penting dalam desain penelitian studi kasus, yaitu :

1. Pertanyaan-pertanyaan penelitian

Strategi studi kasus merupakan strategi yang paling cocok digunakan untuk tipe pertanyaan "Bagaimana" seperti yang digunakan dalam penelitian ini. Pertanyan bagaimana digunakan karena peneliti ingin mengetahui sebuah proses dalam akad murabahah dan musyarakah mutanaqishah pada pembiayaan kepemilikan rumah terhadap kesesuainfatwa DSN-MUI.

2. Unit-unit analisis

Unit analisis merupakan komponen yang secara fundamental berkaitan dengan masalah penentuan kasus dalam penelitian yang bersangkutan. Penelitian terdahulu dapat menjadi tuntunan dalam menetapkan kasus dan unit analisis. Dalam penelitian ini terdapat beberapa poin unit analisis yang akan diteliti yaitu prosedur, persyaratan, penanganan kolektabilitas pembiayaan yang ada pada Bank Jatim Syariah.

3. Kriteria untuk mengintrepretasikan temuan

Komponen keempat ini juga tidak meiliki satupun cara yang tepat yang dapat digunakan untuk menyusun kriteria guna menginterpretasikan tipe-tipe data temuan. Dalam penelitian ini mengaitkan kedua jenis data yaitu indikator yang diberikan terhadap fatwa DSN-MUI dengan fakta yang terjadi dalam pelaksanaan produk pembiayaan kepemilikan rumah di bank jatim syariah yang menggunakan akad murabahah, dengan begitu dapat ditarik kesimpulan atau hasil yang memberikan gambaran apakah produk pembiayaan kepemilikan rumah di bank jatim syariah sudah sesuai dengan fatwa DSN-MUI.

Alasan penggunaan strategi studi kasus yang pertama memungkinkan hasil penelitian sulit untuk dimanipulasi, yang kedua merupakan strategi yang sesuai dengan pertanyaan penelitian dalam peneliti ini. Yang ketiga fokus penelitian terketak pada kesesuaian fatwa DSN-MUI tentang akad murabahah terhadap pembiayaan kepemilikan rumah di bank jatim syariah, sehingga data yang diperoleh dari hasil wawancara dan observasi langsung di lapangan.

\section{Ruang Lingkup Penelitian}

Rumusan masalah yang merupakan fokus studi dalam sebuah penelitian kualitatif menjadi acuan dalam menentukan ruang lingkup penelitian. Apakah pembiayaan kepemilikan rumah menggunakan akad pembiayaan murabahah di bank jatim unit usaha syariah sudah sesuai fatwa DSN-MUI atau tidak. Pengawasan disini meliputi persyaratan dan prosedur pembiayaan murabahah, harga, denda, jaminan, pembiayaan macet dalam produk pembiayaan kepemilikan rumah. 


\section{Jenis dan Sumber Data}

Jenis data yang digunakan pada skripsi ini adalah data primer dan data sekunder. Data primer adalah data yang diperoleh langsung dari sumbernya melalui wawancara dan observasi langsung dari lapangan. Data sekunder adalah data yang diperoleh dari sumber kedua dari data yang kita butuhkan atau peneliti dengan informan tidak terjadi hubungan secara langsung melainkan peneliti mengambil data dari peneliti lainnya (Bungin,2005 :128). Data primer sebagai data utama dalam penelitian ini, akan didapatkan dengan wawancara yang mendalam dan observasi langsung di Bank Jatim Syariah.

Sumber data dalam penelitian ini berasal dari informan utama dan data penunjang yang memiliki kaitan dengan penelitian informan utama (Key Informan) dalam penelitian ini adalah pegawai Bank Jatim Unit Usaha Syariah bagian pembiayaan. Data penunjang dalam penelitian ini merupakan data tentang Bank Jatim Syariah yang berasal dari buku, internet, laporan pembiayaan, dan brosur yang memiliki kaitan dengan penelitian.

\section{Teknik Pengumpulan Data}

Sugiyono (2013 : 73) menjelaskan ada beberapa macam wawancara yaitu wawancara terstruktur, semiterstruktur, dan tidak terstruktur.

a. Wawancara terstruktur adalah dalam pengumpulan data yang telah menyiapkan instrumen penelitian berupa pertanyaan-pertanyaan yang akan ditanyakan oleh informan. Dengan wawancara terstruktur ini setiap responden diberi pertanyaan yang sama, dan pengumpul data mecatatnya.

b. Wawancara semiterstruktur adalah dimana peneliti dalam pelaksanaannya melakukan wawancara lebih bebas bila dibanding dengan wawancara terstruktur. Tujuan dari wawancara ini untuk menemukan permasalahan secara lebih terbuka dimana pihak yang diajak wawancara dimintai pendapat.

c. Wawancara tidak terstruktur adalah wawancara yang bebas dimana peneliti tidak menggunakan pedoman wawancara yang sudah tersusun secara sistematis dan lengkap untuk pengumpulan data. Pedoman yang digunakan hanya berupa garis besar permasalahan yang akan ditanyakan.

Penelitian ini menggunakan wawancara terstruktur, dimana peneliti membuat daftar pertanyaan yang sama terkait dengan penelitian yang sedang diteliti, kemudian peneliti memberi pertanyaan kepada informan.

\section{Teknik Analisis Data}

Data-data yang diperoleh dari berbagai sumber diperlukan pengecekan lebih lanjut untuk memenuhi syarat objektivitas dan kredibilitas yakni melalui proses triangulasi teknik dimana dilakukan pengecekan data kepada sumber yang sama dengan teknik berbeda (Yin, 2009 
:171). Setelah proses triangulasi teknik data yang diperoleh dianalisis melalui tiga alur sebagai berikut (Yin, 2009 : 28,96-97).

1. Reduksi data : tahap pemilihan datadata yang telah diperoleh melalui wawancara, studi dokumen, dan observasi sehingga didapatkan data yang pokok dan fokus pada obyek penelitian.

2. Display data: tahap penyajian data ini yang telah diperoleh melalui proses reduksi dikategorikan berdasarkan pokok permasalahan dan disusun kedalam satu pola untuk memudahkan peneliti melihat hubungan data satu dengan data lainnya.

3. Verifikasi : tahap penarikan kesimpulan berdasarkan data yang telah tersaji dan telah di cross check dengan poinpoin yang menjadi kriteria pokok pada fokus penelitian.

Proses analisa data selanjutnya didasarkan pada proposisi teoritis yang telah ditentukan. Hal ini berguna untuk membantu dan menuntun analis agar bukti data yang diperoleh dapat diperlakukan secara wajar, dapat menghasilkan konklusi analis yang mendukung, dan menetapkan alternative intrepretasi (Yin, 2009 :135137).

Proses analisa data dapat dilakukan sebelum di lapangan dan saat di lapangan. Sugiyono (2010 :245-246) mengatakan bahwa dalam analisis yang dilakukan dengan cara peneliti menganalisis terhadap data berdasarkan hasil studi pendahuluan atau dari data sekunder yang digunakan untuk menentukan fokus penelitian. Fokus penelitian tersebut bersifat sementara dan akan berkembang setelah peneliti benarbenar menjalankan penelitiannya.

Adapun analis data saat di lapangan di lakukan saat wawancara. Pada saat itu peneliti sudah dapat melakukan analisis terhadap jawaban yang di sampaikan narasumber. Apabila berdasarkan analisis terhadap jawaban belum memuaskan,maka akan disampaikan pertanyaan lagi sampai data yang diperoleh dianggap sudah kredibel.

\section{HASIL DAN PEMBAHASAN}

\section{Harga KPR, Margin dan Biaya Lainnya}

Bank Jatim Unit Usaha Syariah menetapkan nominal pembiayaan KPR yaitu pembiayaan minimal yang di patok oleh bank mulai dar Rp. 100.000.000 hingga mencapai Rp. 500.000.000. Dalam Hal ini Bank Jatim Unit Usaha Syariah juga memperhatikan kesanggupan nasabah dalam melakukan pembayaran angsuran. Haris (2007 :119) menjelaskan penjual dan pembeli harus memperoleh harga kesepakatan dengan memberi informasi kepada pembeli berapa harga objek akad serta berapa keuntungan yang diperoleh oleh penjual.

Agar proses pencairan pembiayaan KPR iB Griya Barokah berjalan dengan lancar, ada beberapa biaya yang harus dibayar oleh nasabah 
dan biaya tersebut sudah di tetapkan oleh Bank Jatim Unit Usaha Syariah dengan pihak ketiga yang telah melakukan kerjasama dengan Bank Jatim Unit Usaha Syariah untuk mengurus segala sesuatu yang berhubungan dengan KPR iB Griya Barokah antara lain biaya asuransi, biaya materai, biaya pembukaan rekening bagi nasabah yang belum mempunyai rekening Bank Jatim, dan biaya notaris

\section{Uang Muka KPR iB Griya Barokah}

Untuk melakukan pembiayaan awal nasabah harus menyetorkan vang muka atau DP untuk rumah pertama sebesar $10 \%$, untuk rumah kedua sebesar $20 \%$, untuk rumah ketiga $30 \%$, dst untuk kelipatan 10\%. Karim (2007 :115) menjelaskan akad murabahah pidak penjual boleh meminta uang muka atas kesepakatan antara penjual dan pembeli. Uang muka ini dilakukan dengan tujuan sebagai bukti keseriusan nasabah atau pembeli dalam melakukan pembelian yang diperjanjikan diawal akad seperti yang telah diajarkan oleh Nabi Muhammad SAW.

Uang muka tersebut sudah ditentukan oleh pihak mengikuti kebijakan yang dikeluarkan oleh Bank Indonesia tentang adanya LTV (Load To Valve) adalah porsi kredit dari sebuah pembelian rumah. LTV dari $\mathrm{BI}$ saat ini untuk luas bangunan $>70 \mathrm{~m}^{2}$ maka ptalfond yang diberikan $70 \%$ dengan asumsi $30 \%$ merupakan uang muka yang harus dibayarkan nasabah. Untuk luas bangunan $<70 m^{2}$ platfond nya $80 \%$ dengan asumsi $20 \%$ uang muka nasabah. Dengan LTV nasabah dengan kredit rumah kedua, ketiga, dst harus membayar vang muka lebih mahal dibandingkan dengan kredit rumah pertama.

Dalam hal vang muka ini Bank Jatim Syariah sesuai dengan Fatwa DSNMUI No.13/DSN-MUI/IX/2000 tentang uang muka dalam murabahah dalam butir kedua dijelaskan bahwa besar jumlah vang muka ditentukan berdasarkan kesepakatan. Dalam praktiknya Bank Jatim Syariah pada awal perjanjian telah memberitahukan berupa uang muka awal yang harus dibayar nasabah dengan begitu telah terjadi kesepakatan antara pihak bank dan nasabah.

\section{Jaminan}

Jaminan adalah aset pihak peminjam yang diberikan kepada pihak pemberi pinjaman, dengan tujuan untuk menjamin pembayaran kembali utang murabahah. Nasabah wajib memberikan jaminan kepada pihak bank seperti SHGB, SHM, sebagai persyaratan jaminan. Apabila nasabah melakukan kesengajaan tidak membayar angsuran atas pembiayaan rumah, maka jaminan tersebut menjadi hak milik bank. Jaminan tersebut diberikan oleh pihak nasabah kepada bank sebagai tanda keseriusan nasabah dalam komitmen melakukan transaksi pembiayaan, jaminan, tersebut digunakan untuk melakukan antisipasi resiko apabila kedepannya nasabah tidak serius dalam melakukan pembayaran an 
Muhammad (2002 :269) menjelaskan sebagian besar bank syariah memberlakukan upaya reschedulling, reconditioning, dan pembiayaan ulang dalam bentuk al-Qardu-Hasan. Jika memang ada nasabah yang mengalami kredit macet namun dalam hal penyitaan jaminan bank syariah harus mengutamakn simpati, empati dan menekan. Simpati adalah sopan, menghargai, dan fokus ke tujuan penyitaan. Empati adalah mengerti keadaan nasabah, membangkitkan kesadaran nasabah untuk mengembalikan utangnya. Menekan adalah tindakan terakhir yang dilakukan oleh pihak bank apabila dua tindakan sebelumnya tidak diperhatikan oleh nasabah.

Bank Jatim Syariah dalam prakteknya jika terjadi pembiayaan macet yang disebabkan force majeur atau wanprestasi oleh nasabah bank akan menghubungi nasabah terlebih dahulu apakah dalam pelunasannya pihak keluarga dapat melunasi, apabila nasabah benar-benar belum bisa melunasi pembiayaannya, maka pihak bank akan memberi kelonggaran dengan cara memperpanjang jangka waktu sehingga angsuran semakin kecil dengan begitu nasabah mendapat keinginan pembayaran oleh bank. Namun jika diberi kelonggaran pihak nasabah idak ada upaya untuk melunasi angsuran kembali dengan terpaksa jaminan yang menjadi sertifikat rumah menjadi milik bank.

\section{Denda}

Pada pembiayaan seperti KPR seringkali terjadi resiko penundaan pembayaran atau gagal bayar. Pada awal prosedur pembiayaan telah dihitung berapa kemampuan nasabah apabila melakukan angsuran pembiayaan, hal tersebut dilakukan untuk meningkatkan nasabah dalam hal pembayaran selain itu juga digunakan menghindari resiko gagal bayar. Bagi nasabah yang mampu membayar, tetapi menunda-nunda pembayaran dengan sengaja maka pihak bank jatim syariah memberikan sanksi berupa denda dengan tujuan supaya nasabah lebih disiplin dalam melakukan kewajibannya untuk membayar angsuran setiap bulannya sampai jatuh tempo yang telah disepakati diawal perjanjian.

Bank Jatim Syariah dari awal perjanjian akad telah menjelaskan berapa nominal denda yang harus dibayar nasabah pada saat terjadi keterlambatan pembayaran angsuran saat jatuh tempo. Denda berlaku 15hari setelah jatuh tempo. Denda yang diberikan pihak bank kepada nasabah yang melakukan pembiayaan macet ditentukan berdasarkan besarnya angsuran yaitu sebesar 0-Rp. $1.000 .000=$ Rp. 50.000 , Rp. 1.000.000. - Rp. $2.000 .000=$ Rp. 100.000 , Rp. $2.000 .000-$ Rp. $3.000 .000=$ Rp. $150.000 \mathrm{dst}$ berkelipatan Rp. 50.000 .

Pada fatwa DSN-MUI No.17/DSNMUI/IX/2000 butir pertama nomer lima dijelaskan bahwa sanksi dapat berupa denda sejumlah uang yang besarnya 
ditentukan atas dasar kesepakatan dn dibuat saat akad ditandatangani. Dalam prakteknya Bank Jatim Syariah telah sesuai dengan fatwa DSN-MUI, karena denda yang diberikan telah dijelaskan pada saat awal pelaksanaan akad. Namun besarnya jumlah denda yang didasarkan pada besarnya angusran adalah tidak sesuai dengan fatwa DSNMUI.

Dana yang berasal dari denda tersebut dimasukkan kedalam dana kebajikan atau dana sosial, tidak masuk hasil keuntungan Bank Jatim Syariah. Fatwa DSN-MUI NO. 17/DSN-MUI/IX/2000 butir keenam menjelaskan dana yang berasal dari denda masuk kedalam dana sosial tidak bercampur dengan laporan kevangan Bank Jatim Syariah.

Penyelesaian kolektabilitas pembiayaan macet

Semua surat peringatan 1 hingga 3 sudah dikeluarkan kepada nasabah apabila nasabah berada dalam kategori kolektabilitas 5 atau macet. Jika tidak ada tanggapan dan itikad baik dari nasabah untuk melunasi angsurannya sesuai dengan jumlah dan waktu yang disepakati, maka pihak bank akan melakukan lelang. Obyek yang dijadikan lelang adalah rumah yang dibiayai sebagai jaminan tersebut.

Pada Fatwa DSN-MUI N0.47/DSNMUI/II/2005 butir satu dijelaskan bahwa obyek murabahah atau jaminan lainnya dijual oleh nasabah kepada atau melalui lembaga keuangan syariah dengan harga pasar yang disepakati, butir kedua dijelaskan nasabah melunasi sia utangnya kepada lembaga keuangan syariah dari hasil penjualan, butir ketiga dijelaskan apabila hasil penjualan melebihi sisa utang maka lembaga keuangan syariah mengembalikan sisanya kepada nasabah. Dalam prakteknya Bank Jatim Syariah tekah sesuai fatwa diatas karena pihak bank melakukan sistem lelang dengan harga disesuaikan kesepakatan awal dengan nasabah, nasabah melunasi sisa utangnya dari hasil lelang tersebut, dan pihak bank akan mengembalikan sisa hasil lelang jika melebihi sisa utang nasabah.

\section{v. KESIMPULAN DAN SARAN}

\section{Simpulan}

Kesimpulan dari hasil penelitian tentang Kesesuaian Akad Murabahah Dan pada Pembiayaan Kepemilikan Rumah Bank Jatim Unit Usaha Syariah di lihat dari empat indikator yaitu harga, denda, jaminan, pembiayaan macet yang disesuaikan dengan Fatwa DSN MUI No. 04/DSN-MUI/IV/2000 tentang murabahah, No. 13/DSN-MUI/IX/2000 tentang uang muka murabahah, No. 17/DSN-MUI/IX/2000 tentang sanksi atas nasabah mampu yang menunda-nunda pembayaran.

N0.47/DSN-MUI/II/2005 tentang penyelesaian murabahah bagi nasabah yang tidak mampu membayar, dalam prakteknya Bank Jatim Syariah telah sesuai dengan fatwa DSN-MUI hanya ada satu poin yaitu pada poin denda yang tidak sesuai dengan fatwa 
DSN-MUI karena didalam fatwa menyebutkan bahwa sanksi dapat berupa denda sejumlah uang yang besarnya ditentukan atas dasar kesepakatan, tetapi dalam prakteknya besarnya denda yang ditetapkan pihak Bank Jatim Syariah bergantung pada besarnya angsuran yang ditetapkan diawal perjanjian.

\section{Saran}

1. Pihak Bank Jatim Syariah

Seharusnya pihak Bank Jatim Unit Usaha Syariah lebih gencar lagi melakukan pemasaran terkait produk KPR kepada masyarakat sehingga semakin dikenal luas, serta melengkapi data data terkait alur produk KPR terutama pada akad yang sesuai pada pembiayaan KPR. Terkait denda sebaiknya ditentukan berdasarkan waktu bukan dari angsurannya.

\section{Peneliti Selanjutnya}

Diharapkan untuk dapat mengkaji lebih dalam tentang kesesuaian penanganan kolektabilitas pembiayaan KPR, khususnya terkait faktor yang mempengaruhi penurunan kolektabilitas pembiayaan macet apakah dalam prakteknya bank syariah sudah sesuai prinsip syariah atau tidak serta bagaimana tanggapan nasabah terkait produk pembiayaan kepemilikan rumah syariah.

\section{DAFRAR PUSTAKA}

Antonio, Muhammad Syaf'i. 2001. Bank Syariah : dari teori ke praktek. Jakarta: Gema Insani.
Arifin, Zainul. 2009. Dasar-Dasar Manajemen Bank Syariah. Jakarta: Kelompok Pustaka Alvabet.

Ascarya. 2011. Akad dan Produk Bank Syariah. Jakarta: PT. Rajawali Pers.

Bungin, Burhan. 2005. Penelitian Kualitatif: Komunikasi, Ekonomi, Kebijakan Publik dan IImu Sosial Lainnya. Jakarta. Balai Pustaka.

Hari Haris, Helmi. 2007. Pembiayaan Kepemilikan Rumah (Sebuah Inovasi Pembiayaan Perbankan Syariah). Jurnal Ekonomi Islam La Riba vol.1 No.1 (online) (http://journal.uii.ac.id) diakses pada 7 Agustus 2015.

Ibrahim, Ahmad. 2006. Manajemen Syariah. Jakarta: PT Raja Grafindo Persada.

Ismail. 2011. Perbankan Syariah. Jakarta: PT Fajar Interpratama Offset.

Karim, Adiwarman. 2007. Bank Islam Analisis Figh dan Keuangan. Jakarta: PT Rajawali Pers.

Kountur, R. 2004. Manajemen Risiko. Jakarta: Abdi Tandur.

Kuncoro, Mundrajad. 2002. Manajemen Perbankan: Teori dan Aplikasi. Yogyakarta: BPFE Yogyakarta.

Manullang. $2006 . \quad$ Dasar-Dasar Manajemen. Yogyakarta: Gadjah Mada University Press.

Muhammad. 2000. Sistem dan Prosedur Operasional Bank Syariah. Yogyakarta: UII Press.

Muhammad. 2004. Manajemen Dana Bank Syariah. Yogyakarta: Ekonisia. 
Muhammad. 2005. Bank Syariah : Analisis

Kekuatan, Peluang, Kelemahan

dan Ancaman. Yogyakarta:

Ekonisia. 